Vol. 11 (2): 217-222 (2021)

\title{
INFLUENCE OF ADDITIVES ON THE QUALITY OF BREAD PRODUCED FROM CERTAIN TYPES OF FLOUR
}

\author{
Arsim Elshani ${ }^{1}$, Ibrahim Hoxha ${ }^{2 *}$, Gafur Xhabiri ${ }^{3}$ Nexhdet Shala $^{4}$, Nazmi Hasanaj ${ }^{5}$ \\ 1,2*4,5 University of Haxhi Zeka, Faculty of Agribusiness, Department of Food technology, Peja 30000, Kosovo; \\ ${ }^{3}$ State University of Tetova, Faculty of Food Technology and Nutrition, Tetova, North Macedonia; \\ ${ }^{4,5}$ Seed Producer "Koal Seed", Istog 31000, Kosovo; \\ *Corresponding Author Ibrahim Hoxha, e-mail: ibrahim.hoxha@unhz.eu; \\ arsim.elshani@unhz.eu; earsim@hotmail.com;
}

Received January 2021; Accepted February 2021; Published March 2021;

DOI: https://doi.org/10.31407/ijees11.204

\begin{abstract}
The main technological factors on bread production are the number of proteins, respectively the content and the quality of the gliadine and gluteline-gluten, for this reason in case it is necessary, the usage of tested additives leads to the improvement of the quality of final product. The effect of used additives, however, it is closely linked to the used wheat cultivars, as well as to the radius of the flour that will be used for the production of bread. The additives or the redox agents represent products with chemical attributes, which through the oxidation or reduction reactions that they incite in the dough, they change the rheological qualities of it, the oxidants improve the color of the flour, rheological qualities as well as the formation of pores of bread, whereas the reducing agents react in the SS connections in dough, respectively they incite the reduction of overall molecular weight of the protein aggregates of gluten protein.
\end{abstract}

Key words: gluten, radius of bread, taste of bread, volume of bread, xylanase. 